\title{
Factors Controlling Decomposition Rates of Needle Litter Across a Chronosequence of Chinese Pine (Pinus tabuliformis Carr.) Forests
}

\author{
Jing Gao ${ }^{1,2}$, Hairong Han ${ }^{1}$, Fengfeng Kang ${ }^{1 *}$ \\ ${ }^{1}$ College of Forestry, Beijing Forestry University Beijing, China \\ ${ }^{2}$ Institute of Geographic Sciences and Natural Resources Research, Chinese Academy of Sciences, \\ Beijing, China
}

Received: 4 December 2017

Accepted: 24 January 2018

\begin{abstract}
We investigated how factors underlying local spatial variations controlled needle litter decomposition across a chronosequence of Chinese pine (Pinus tabuliformis Carr.) forests. Litterbag methods were used to measure changes in litter chemistry and the mass loss of leaf litter, as well as selective biotic and abiotic factors during the growing seasons (May-October) in 2013 and 2014 in a set of fully replicated P. tabuliformis Carr. secondary forest stands that differ in age in northern China. During the two growing seasons the path analysis identified the litter lignin $/ \mathrm{N}$ ratio, soil microbial metabolic quotient $\left(q \mathrm{CO}_{2}\right)$, soil diversity of fungal assemblages (SFD), and soil-water content (SWC) as dominant controlling factors in needle litter decomposition, collectively explaining $76.9 \%$ of the total variation in mass loss across the entire age sequence. Litter lignin/ $/ \mathrm{N}$ and soil $q \mathrm{CO}_{2}$ had the greatest negative effects on the $\mathrm{k}$ value, followed by weaker positive effects of SFD and SWC. Our findings indicate that forest stand age has a great influence on needle litter decomposition by determining litter quality, with soil microbial activity and local environmental factors being secondary drivers in needle litter decomposition across a chronosequence of Chinese pine (Pinus tabuliformis Carr.) forests.
\end{abstract}

Keywords: litter decomposition, litter quality, environmental factors, Pinus tabuliformis Carr.

\section{Introduction}

Leaf litter decomposition is an important ecological process that regulates the cycle of matter, such as the release of $\mathrm{CO}_{2}$ into the atmosphere and nutrient mineralization in

*e-mail: Fengfeng_Kang@163.com soil, providing the main source of nutrients for biological activity and playing a crucial role in the maintenance of soil fertility in forest ecosystems [1-2]. Generally, the rate of litter decomposition is positively correlated with the $\mathrm{N}$ content of initial litter, while it is negatively correlated with $\mathrm{C} / \mathrm{N}$ and lignin/ $\mathrm{N}$ ratios of initial litter over a wide range of ecosystems [3]. Moreover, environmental conditions, including soil fertility, microclimate, and 
faunal and microbial communities in the forest floor, can also indirectly alter decomposition rates [4]. Particularly, soil microorganisms are the animate component of soil organic matter, and they play essential roles in the transformation from litter to soil organic matter, as well as the formation and development of the soil structure [5]. An in-depth understanding of the determinants of decomposition rates of leaf litter will greatly contribute to understanding the functioning of forest ecosystems.

Currently, the importance of intraspecific variability in litter quality is receiving more attention [6]. Litter quality, which is controlled by species identity, also varies considerably within the same species due to differences in nutrient availability and climate conditions [7]. Although there are many studies on the intraspecific variation of litter quality through genetic variability and environmental heterogeneity, studies on forest stand age as a potential driving factor of intraspecific litter quality variability are scarce [8]. Thus, there is a need for further investigation concerning the forest stand age-associated variability of litter decomposition.

In addition, as a powerful predictor of ecosystem structure and function, forest stand age could affect soil physical and chemical properties and the qualitative and quantitative composition of decomposer communities [9-10] because soil decomposer organisms have speciesspecific feedback interactions with leaf litter quality based on forest stand age in the transformation of litter to soil organic matter, which contributes to the nutrient availability from different root exudates and the litter decomposition of the corresponding forest stand age type [11]. Consequently, the type and quantity of soil microbial communities are influenced by specific forest types at different ages [12]. Soil microbial indicators were applied in litter decomposition programmes because of their essential roles in leaf litter decomposition [5, 10]. Specifically, the major indicators of soil microbial activity are microbial biomass, microbial respiration, microbial diversity, etc. [13].

Additionally, forests of different ages are considered to have distinctive microclimates on the forest floor, such as different soil temperatures and moisture contents [14]. Many studies have described the importance of soil temperature and precipitation on the rates of litter decomposition [15-17]. Wang proposed that the temperature sensitivity of broadleaf litter decomposition was equivalent to that of coniferous needle litter, which varied with the extent of decomposition in a subtropical forest in China [18]. Berbeco observed that soil warming accelerated the decomposition rates of fine woody debris in temperate forests [15]. Cortez attributed the predominant control of litter decomposition to soil temperature and moisture limitations [17]. Therefore, it is necessary to observe whether or not the soil temperature and moisture content in the chronosequence stands influence needle litter decomposition.

As a result, variations in both litter quality and environmental conditions in forest stands may result in the spatial heterogeneity of decomposition rates of litter at different ages. However, the relative contributions of various factors in controlling the decomposition rates of needle litter across a chronosequence of Chinese pine forests are poorly understood.

In this study, we investigated needle litter decomposition across a chronosequence of Chinese pine forests in northern China, including young ( $\leq 30$-year-old), middle-aged (40-year-old), immature (50-year-old), and mature (60-year-old) stands. Specifically, the objectives of the study were to identify the dominant controlling factors and their relative contributions to variations in the decomposition of needle litter across a chronosequence of Chinese pine forests.

\section{Materials and Methods}

\section{Site Description}

The study was carried out in the Liao River Source Nature Reserve (LRSNR, 41 $01^{\prime}-41^{\circ} 21^{\prime} \mathrm{N}, 118^{\circ} 22^{\prime}$ $\left.118^{\circ} 37^{\prime} \mathrm{E}\right)$, Pingquan County, Hebei Province, China. This nature reserve occupies an area of $3.356 \times 10^{4} \mathrm{hm}^{2}$ with elevation ranging from $625 \mathrm{~m}$ to $1,738 \mathrm{~m}$. The region is in the transition area between the temperate to coldtemperate zones. Long-term mean annual precipitation is $550 \mathrm{~mm}$, occurring mainly in June to September. The mean annual temperature is $7.3^{\circ} \mathrm{C}$ with monthly average temperature ranging from $-10.8^{\circ} \mathrm{C}$ (January) to $22.9^{\circ} \mathrm{C}$ (July). The annual frost-free period is 115-130 days, with an early frost in October and late frost in April. Soil type is brown soil and cinnamon soil classified as Eutriccambisol [19].

\section{Experimental Design}

This work was conducted based on the Forestry Standards "Observation Methodology for Long-term Forest Ecosystem Research" of the People's Republic of China (LY/T 1952-2011) [20].

Pinus tabuliformis Carr., which is an endemic and widespread native conifer species in northern China, spans from $31^{\circ} 13^{\prime} \mathrm{N}$ to $43^{\circ} 33^{\prime} \mathrm{N}$ and from $103^{\circ} 20^{\prime} \mathrm{E}$ to $124^{\circ} 45^{\prime} \mathrm{E}$, covering almost $228.10 \times 10^{4}$ ha of forestland in China. Moreover, P. tabuliformis Carr. is a woody perennial and primarily pioneer species of secondary succession [5]. In the study sites, there are four age groups of P. tabuliformis Carr, which were natural regeneration, including $\leq 30,40,50$, and 60-year-old stands, representing young, middle-aged, immature, and mature stands, respectively. For each forest stand age group we established three $20 \times 30 \mathrm{~m}$ permanent replicate plots $50 \mathrm{~m}$ apart, which have similar landscape position, topographic features, elevation, and exposure to ensure comparability between test results. Detailed information for these four sites is shown in Table 1.

In 2012 we collected freshly senesced leaves of $P$. tabuliformis Carr from the forest floor under four forest stand age stands. All of the litter was air dried until 
Table 1. Site characteristics and physiochemical properties of the top soil layer $(0-5 \mathrm{~cm})$ of Pinus tabuliformis Carr. natural secondary forests (means \pm standard error, $n=3$ ).

\begin{tabular}{|c|c|c|c|c|}
\hline & \multicolumn{4}{|c|}{ Forests age classes } \\
\hline & Young & Middle-aged & Immature & Mature \\
\hline \multicolumn{5}{|c|}{ Stand characteristics } \\
\hline Tree density $\left(\right.$ ha $\left.^{-1}\right)$ & 1,900 & 1,050 & 930 & 430 \\
\hline Slope angle $\left(^{\circ}\right)$ & 27 & 23 & 25 & 19 \\
\hline Aspect & East & East & East & East \\
\hline Elevation (m) & 1,018 & 985 & 1,006 & 992 \\
\hline Mean DBH (cm) & $11.75 \pm 1.05 \mathrm{a}$ & $17.16 \pm 1.96 b$ & $23.17 \pm 6.69 \mathrm{c}$ & $34.05 \pm 9.10 \mathrm{~d}$ \\
\hline Tree height (m) & $10.2 \pm 2.7 \mathrm{a}$ & $14.9 \pm 4.2 b$ & $17.3 \pm 4.4 \mathrm{c}$ & $19.8 \pm 3.5 \mathrm{~d}$ \\
\hline Litter layer depth $(\mathrm{cm})$ & $1.87 \pm 0.45 \mathrm{a}$ & $2.23 \pm 0.55 \mathrm{a}$ & $3.51 \pm 0.52 b$ & $4.78 \pm 0.48 \mathrm{c}$ \\
\hline \multicolumn{5}{|c|}{ Soil characteristics } \\
\hline $\mathrm{SOC}\left(\mathrm{g} \cdot \mathrm{kg}^{-1}\right)$ & $23.72 \pm 0.57 \mathrm{a}$ & $24.97 \pm 0.41 b$ & $27.48 \pm 0.24 \mathrm{c}$ & $29.15 \pm 0.31 d$ \\
\hline $\mathrm{TN}\left(\mathrm{g} \cdot \mathrm{kg}^{-1}\right)$ & $0.91 \pm 0.05 \mathrm{a}$ & $1.22 \pm 0.05 b$ & $1.51 \pm 0.07 \mathrm{c}$ & $1.64 \pm 0.04 \mathrm{~d}$ \\
\hline $\mathrm{TP}\left(\mathrm{g} \cdot \mathrm{kg}^{-1}\right)$ & $0.23 \pm 0.05 \mathrm{a}$ & $0.38 \pm 0.04 b$ & $0.59 \pm 0.04 \mathrm{~d}$ & $0.48 \pm 0.03 \mathrm{c}$ \\
\hline $\mathrm{TK}\left(\mathrm{g} \cdot \mathrm{kg}^{-1}\right)$ & $4.23 \pm 0.07 b$ & $3.98 \pm 0.08 \mathrm{a}$ & $4.25 \pm 0.05 b$ & $4.48 \pm 0.04 \mathrm{c}$ \\
\hline Soil bulk density $\left(\mathrm{g} \cdot \mathrm{cm}^{-3}\right)$ & $1.49 \pm 0.15 \mathrm{c}$ & $1.41 \pm 0.14 b$ & $1.40 \pm 0.11 \mathrm{~b}$ & $1.33 \pm 0.26 \mathrm{a}$ \\
\hline $\mathrm{pH}$ value & $6.01 \pm 0.05 \mathrm{a}$ & $6.45 \pm 0.05 \mathrm{c}$ & $6.32 \pm 0.04 b c$ & $6.22 \pm 0.03 b$ \\
\hline
\end{tabular}

Values designated by the different letters within a variable are significantly different at $p<0.05$; DBH, diameter at breast height, SOC, soil organic carbon content, TN, total nitrogen content, TP, total phosphorus, TK, total potassium, $\mathrm{pH}$, soil $\mathrm{pH}$ value

constant weight after collection and stored for the litter decomposition test. In order to calculate the correction factor from air-dried to oven-dried weight, five subsamples of the litter were dried to a constant weight at $70^{\circ} \mathrm{C}$.

A litterbag method was used for estimating rates of leaf litter decomposition, a widely used technique to determine litter mass loss, during a 24-month period. Each litterbag $(20 \times 30 \mathrm{~cm})$ made from polyethylene netting with a $1.0 \times 1.5 \mathrm{~mm}$ mesh size. Each bag was filled with $10 \mathrm{~g}$ of air-dried litter with a weight accuracy of $10^{-3} \mathrm{~g}$, labeled and sealed with rust-proof staples.

On 19 October, 2012, 288 litterbags (4 forest stand ages $\times 3$ litter-bag replicates $\times 3$ replicate plots $\times 8$ harvests) were deployed between the litter layer and the soil horizon in a random arrangement and fastened to the ground with non-corrosive nails in their corresponding forest aging plots.

\section{Litterbag Sampling and Analysis}

Litterbags of each litter at four forest-stand ages were randomly retrieved after 144, 216, 288, 360, 504, 576, 648 , and 720 days of decomposition. The litter remaining in each bag was cleaned from extraneous matter, such as attached soil particles, in-growth plant materials and small animals, using tweezers and a brush. In the end, the litter-samples were oven-dried at $70^{\circ} \mathrm{C}$ for $72 \mathrm{~h}$ to reach a constant mass and then weighed to determine the remaining dry leaf mass.

\section{Chemical Analyses of Litter}

Subsamples of the initial leaf litter at four forest stand ages and each litter sample harvested during decomposition were ground to fine powder with a micro-plant mill. All analyses were carried out on three sub-samples. Total $\mathrm{C}$ content was determined using the $\mathrm{H}_{2} \mathrm{SO}_{4}-\mathrm{K}_{2} \mathrm{Cr}_{2} \mathrm{O}_{7}$ oxidation method [21]. Total $\mathrm{N}$ concentration was determined with an azotometer (Kjeltec 2300, Foss, Sweden) after $0.5 \mathrm{~g}$ sub-samples had been digested in $10 \mathrm{ml}$ of concentrated $\mathrm{H}_{2} \mathrm{SO}_{4}$ mixed with $5 \mathrm{ml}$ of $\mathrm{H}_{2} \mathrm{O}_{2}$. The concentration of total $\mathrm{P}$ was measured using the ammonium molybdate method followed by a colorimetric analysis at $880 \mathrm{~nm}$ after acid digestion [22]. Lignin concentration was determined using the aciddetergent fibre procedure [23].

\section{Soil Sampling and Analysis}

Soil temperatures were measured with the temperature sensor attached to an automated soil $\mathrm{CO}_{2}$ flux system (LI-8100, Li-Cor Inc., Lincoln, NE, USA), and the gravimetric soil water content $(\% \mathrm{SWC})$ was calculated from the mass loss after drying soil samples to a constant weight $\left(105^{\circ} \mathrm{C}, 48 \mathrm{~h}\right)$ periodically at each sampling time. 
Due to the majority of microorganism distribution between soil depths of $0 \mathrm{~cm}$ and $20 \mathrm{~cm}$ [24], soil samples were sampled between $0 \mathrm{~cm}$ and $5 \mathrm{~cm}$. In each replicate plot, three soil samples were collected randomly between $0 \mathrm{~cm}$ and $5 \mathrm{~cm}$ respectively after the removal of the upper three litterbags, using a stainless steel soil auger $(3 \mathrm{~cm}$ in diameter), which were mixed thoroughly to obtain homogeneous composite soil samples.

Soil samples were sieved moist through a $2-\mathrm{mm}$ sieve and stored at $4^{\circ} \mathrm{C}$ until soil microbial parameters were performed. All microbial parameters were performed within 7 days of sampling [25].

\section{Soil Microbial Biomass Carbon}

The microbial biomass carbon (MBC) of soil samples was determined by the chloroform fumigation and extraction methods, using 0.38 as a conversion factor to convert extracted carbon by $0.5 \mathrm{M} \mathrm{K}_{2} \mathrm{SO}_{4}$ to MBC [26].

\section{Soil Microbial Respiration}

Soil microbial respiration (MR) was measured by the alkali absorption method to quantify $\mathrm{CO}_{2}$ production at $28^{\circ} \mathrm{C}$ in the dark for a 6-day period of incubation [27].

\section{Soil Microbial Metabolic Quotient}

The soil microbial metabolic quotient $\left(q \mathrm{CO}_{2}\right)$ was calculated by dividing soil microbial respiration (MR) by the corresponding soil microbial biomass carbon (MBC) [28].

All analyses of the indicators of soil microbial activity were carried out in triplicate with one control, and the values were calculated on the basis of the ovendry $\left(105^{\circ} \mathrm{C}, 48 \mathrm{~h}\right)$ weight of soil.

\section{Soil Diversity of Fungal Assemblages}

The soil diversity of fungal assemblages (SFD) was measured with DNA Extraction and PCR-DGGE, following the experimental procedure in Gao et al. [29].

\section{Calculations}

The remaining litter mass (RM) within each litterbag was calculated by dividing litter dry weight $\left(\mathrm{X}_{\mathrm{i}}\right)$ at each sampling time $\mathrm{i}$ by the initial litter dry weight $\left(\mathrm{X}_{\mathrm{o}}\right)$ using the formula:

$$
\% \mathrm{RM}=X_{i} / X_{O} \times 100
$$

The remaining litter nutrient $(\mathrm{RN})$ within each litterbag was calculated using the formula:

$$
\% \mathrm{RN}=\left(C_{i} / X_{i}\right) /\left(C_{o} / X_{o}\right) \times 100
$$

Specifically, $C_{i}$ was the nutrient concentration at each sampling time $\mathrm{i}$ and $C_{o}$ was the initial nutrient concentration.

To quantify the dynamics of mass loss, we fitted change in the amount of litter over time as a negative exponential decay function, developed by Olson [30] and further refined by Barlocher [31], i.e., $\mathrm{M}_{\mathrm{t}}=\mathrm{M}_{0} \times \mathrm{e}^{-\mathrm{kt}}$, where $M_{t}$ is the remaining mass at time $t, M_{o}$ the initial mass of the litter, $\mathrm{k}$ the rate of decomposition, and $\mathrm{t}$ the incubation time of the litterbags. The time required for $50 \%$ and $95 \%$ mass loss was calculated as $\mathrm{t}_{50 \%}=-\ln 0.5 / \mathrm{k}$ and $\mathrm{t}_{95 \%}=-\ln 0.5 / \mathrm{k}$, respectively [30].

Each detected band was identified as a ribotype, and the number of bands (S) reflected the genotypic richness of each sample [32]. The relative abundance of each band $\left(\mathrm{p}_{\mathrm{i}}\right)$ was expressed as the pixel intensity of the band [33]. The Shannon-Wiener index of richness (H) [34] was calculated with the following equation:

$$
\mathrm{H}=-\sum_{\mathrm{i}=1}^{\mathrm{N}} \mathrm{p}_{\mathrm{i}} \ln \mathrm{p}_{\mathrm{i}}
$$

...where $p_{i}=n_{i} / N, n_{i}$ is the pixel intensity of each band and $\mathrm{N}$ is the total intensity of the sample in a lane.

\section{Statistical Analysis}

A one-way ANOVA was conducted to analyze the significance of the differences in environmental factors (soil temperature, soil water content and soil biophysical factors) among the four stand-age classes, followed by Tukey's test during the sampling time. Repeated ANOVA measurements were applied to examine differences in the remaining mass and chemical dynamics of litter among four stand-age classes. The statistical analyses were performed using SPSS version 13.0.1 statistical software (SPSS, Chicago, IL, USA), with the level of significance set as 0.05 in all cases.

A path analysis was conducted to examine the controls of dominant biotic and abiotic factors on litter decomposition. A path model is an advanced, multivariate statistical technique based on hypothesis testing of complex path-relation networks [35-36]. In the most appropriate path model, correlation analyses were used to examine the relationships of the decomposition rate $(\mathrm{k})$ with all the monitored factors. Among the 11 variables significantly related to litter decomposition (i.e., $\mathrm{SMC}, \mathrm{T}, \mathrm{C} / \mathrm{N}_{\text {litter }}, \% \mathrm{~N}, \% \mathrm{C}, \operatorname{lignin} / \mathrm{N}, \%$ lignin, $\mathrm{MBC}, \mathrm{SMR}, \mathrm{qCO}_{2}$, and SFD), four were chosen in the path analysis due to the autocorrelation among variables, including $\mathrm{SMC}$, lignin/N, $\mathrm{qCO}_{2}$, and SFD. Specifically, lignin/ $\mathrm{N}$ was retained to represent plant trait, $\mathrm{qCO}_{2}$ and SFD as indicators of soil biotic properties, and SMC was considered representative of habitat environmental factors. The analyses were conducted using the maximum likelihood estimation procedures of Amos 17.0 (SPSS, Chicago, IL, USA). 
Table 2. Initial chemical properties of needle litter in Pinus tabuliformis Carr. natural secondary forests (means \pm standard error, $n=3 ; \mathrm{mg} / \mathrm{g})$.

\begin{tabular}{|c|c|c|c|c|}
\hline \multirow{2}{*}{ Litter quality attributes } & \multicolumn{4}{|c|}{ Forest stand age classes } \\
\cline { 2 - 5 } & Young & Middle-aged & Immature & Mature \\
\hline $\mathrm{C}$ & $529.19 \pm 6.16 \mathrm{c}$ & $551.82 \pm 4.13 \mathrm{~b}$ & $564.82 \pm 5.55 \mathrm{a}$ & $570.18 \pm 7.54 \mathrm{a}$ \\
\hline $\mathrm{N}$ & $4.82 \pm 0.12 \mathrm{c}$ & $5.72 \pm 0.15 \mathrm{~b}$ & $6.12 \pm 0.11 \mathrm{a}$ & $6.36 \pm 0.10 \mathrm{a}$ \\
\hline $\mathrm{C} / \mathrm{N}$ & $109.79 \pm 3.9 \mathrm{a}$ & $96.47 \pm 2.6 \mathrm{~b}$ & $92.29 \pm 2.7 \mathrm{bc}$ & $89.65 \pm 3.2 \mathrm{c}$ \\
\hline Lignin & $217.31 \pm 5.03 \mathrm{c}$ & $231.33 \pm 5.14 \mathrm{~b}$ & $239.17 \pm 4.48 \mathrm{a}$ & $244.63 \pm 4.65 \mathrm{a}$ \\
\hline Lignin/N & $45.09 \pm 1.01 \mathrm{a}$ & $40.44 \pm 1.11 \mathrm{~b}$ & $39.08 \pm 0.95 \mathrm{~b}$ & $38.46 \pm 0.92 \mathrm{~b}$ \\
\hline
\end{tabular}

Different letters within the same row indicate significantly different means $(p<0.05$, Tukey's test) among the stands.

\section{Results}

Variations in Soil Characteristics and Initial Litter Chemistry Across Forest Stand Age Classes

Among the chronosequence of Chinese pine forests, the mature forest stands had the highest values of SOC and TN, which decreased in the order of mature $>$ immature $>$ middle-aged $>$ young forest stands. TP varied in the order of immature $>$ mature $>$ middleaged $>$ young forest stands. The highest values of TK occurred in mature forest stands, followed by young/immature forest and middle-aged forest stands. The $\mathrm{pH}$ values of all soil samples in this pine age sequence ranged from 6.01 to 6.45 , meaning the litter was acidic. Soil bulk density showed a decreasing trend with increasing stand age, with litter variation between middle-aged and immature forest stands (Table 1).
Pinus tabuliformis Carr. litter across the chronosequence stands significantly differed in nutrient concentrations and in nutrient stoichiometry. The detailed descriptions are shown in Table 2.

Temporal Patterns of Changes in Soil Temperature and Soil water Content Across Forest Stand Age Classes

Temporal patterns of changes in soil temperature exhibited a distinct seasonal variation consistent with that in the air temperature observed in the study plots (Fig. 1a). The soil temperature ranged from $7.4^{\circ} \mathrm{C}$ to $20.6^{\circ} \mathrm{C}$ during the 2013 growing season, and from $8.5^{\circ} \mathrm{C}$ to $21.9^{\circ} \mathrm{C}$ during the 2014 growing season.

Temporal patterns of changes in soil water content initially showed a fluctuating uptrend during both growing seasons, reaching a peak in August, followed by a rapidly linear decrease to reach the minimum in October (Fig. 1b). There were significant differences
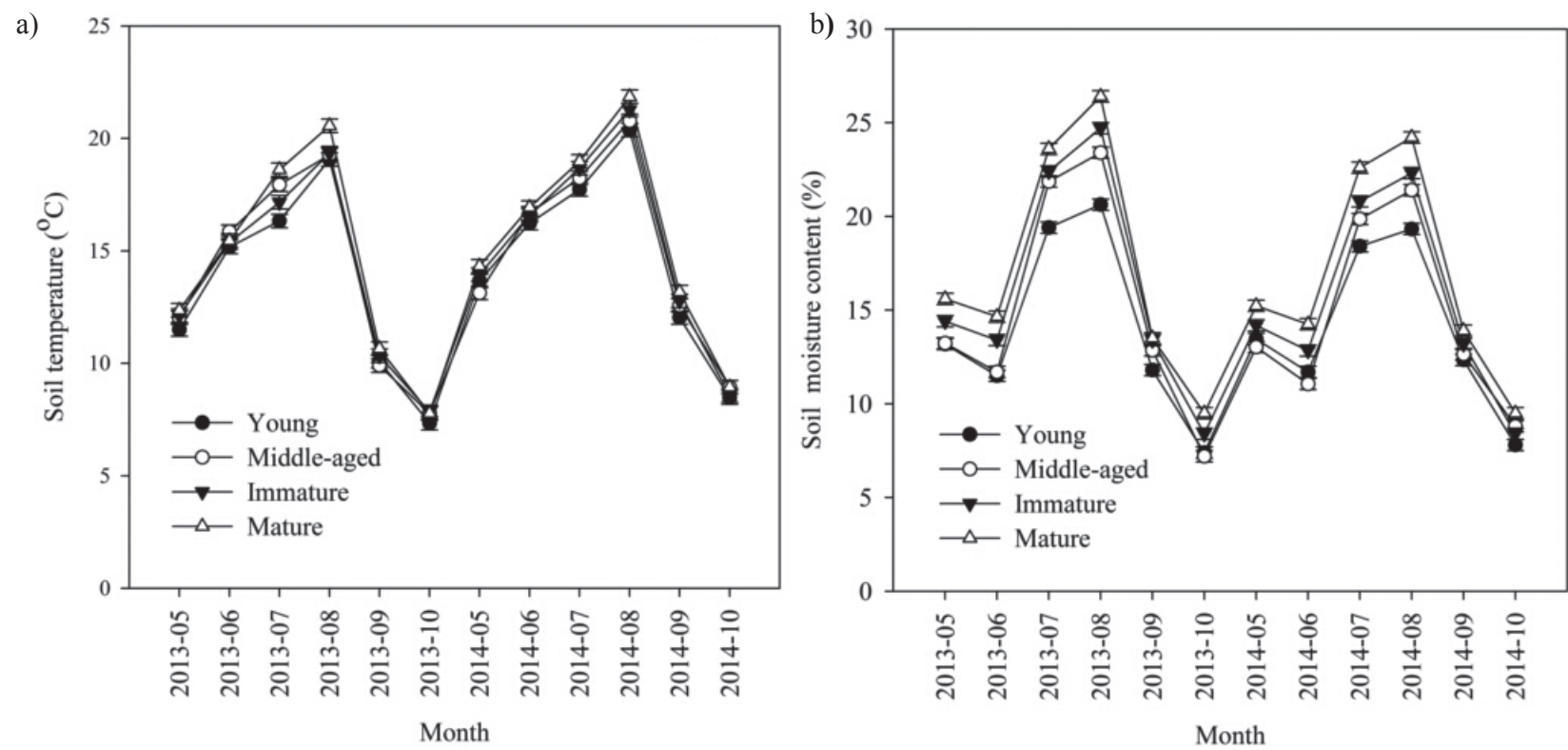

Fig. 1. Seasonal variation in a) soil temperature, $T\left({ }^{\circ} \mathrm{C}\right)$, and b) soil moisture, $M(\%)$, of all four age classes of forest stands during the 2013 and 2014 growing seasons 
Table 3. Decomposition parameters $a$, coefficient $k$, and time $(t)$ required for different levels $\left(t_{50 \%}\right.$ and $t_{95 \%}$ mass loss) of decay of leaf litter in Pinus tabuliformis Carr. forests (means \pm standard error, $n=3$ ).

\begin{tabular}{|c|c|c|c|c|}
\hline Forest stand age classes & Parameter $a$ & Coefficient $k$ & $T_{50 \%}($ year $)$ & $T_{95 \%}($ year $)$ \\
\hline Young & $101.02 \pm 0.13 \mathrm{a}$ & $0.24 \pm 0.01 \mathrm{a}$ & $2.81 \pm 0.04 \mathrm{c}$ & $12.13 \pm 0.23 \mathrm{c}$ \\
\hline Middle-aged & $101.68 \pm 0.11 \mathrm{~b}$ & $0.27 \pm 0.01 \mathrm{~b}$ & $2.56 \pm 0.03 \mathrm{~b}$ & $11.10 \pm 0.25 \mathrm{~b}$ \\
\hline Immature & $101.72 \pm 0.14 \mathrm{~b}$ & $0.28 \pm 0.01 \mathrm{~b}$ & $2.48 \pm 0.05 \mathrm{~b}$ & $10.70 \pm 0.21 \mathrm{~b}$ \\
\hline Mature & $102.18 \pm 0.15 \mathrm{c}$ & $0.32 \pm 0.01 \mathrm{c}$ & $2.16 \pm 0.03 \mathrm{a}$ & $9.36 \pm 0.22 \mathrm{a}$ \\
\hline
\end{tabular}

Values followed by different lower letters in the same line indicate a significant difference between means $(p<0.05)$

a)

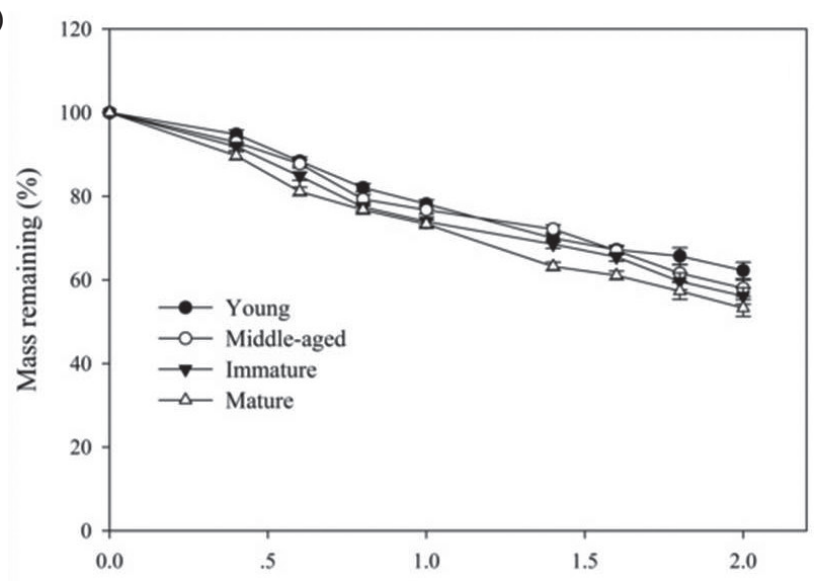

c)

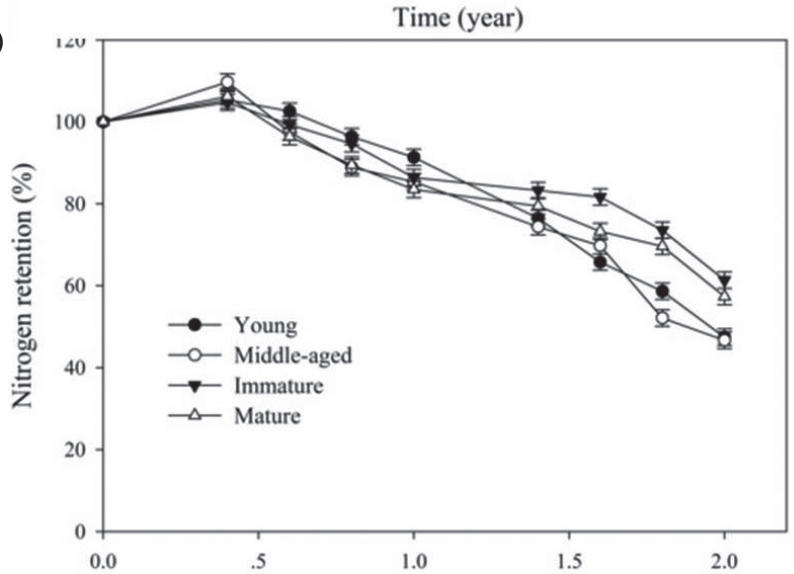

e)

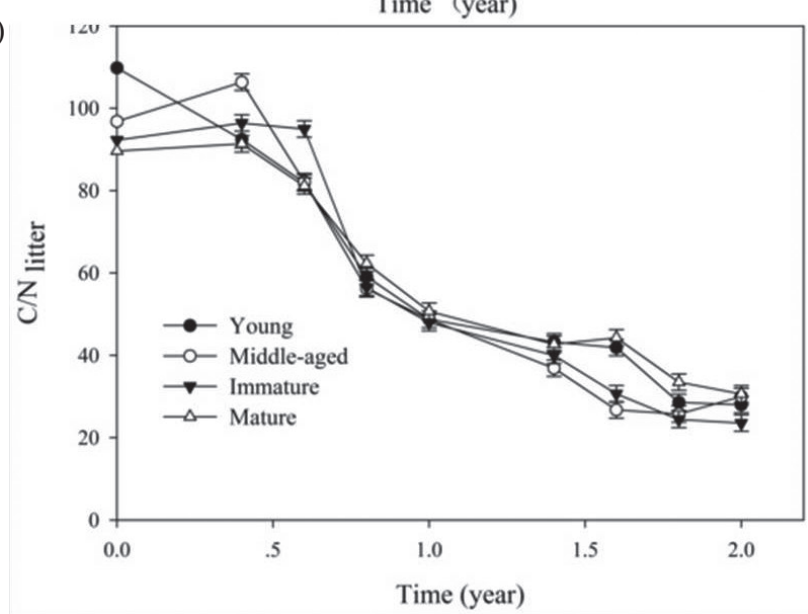

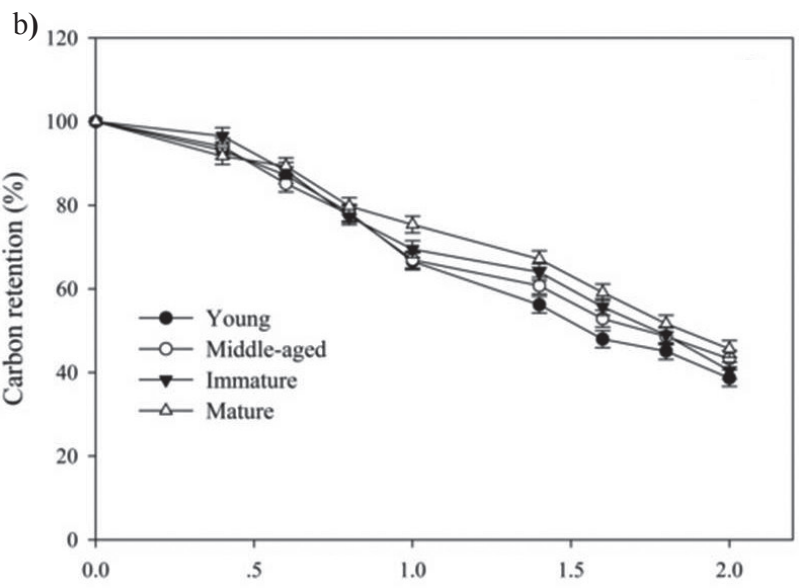
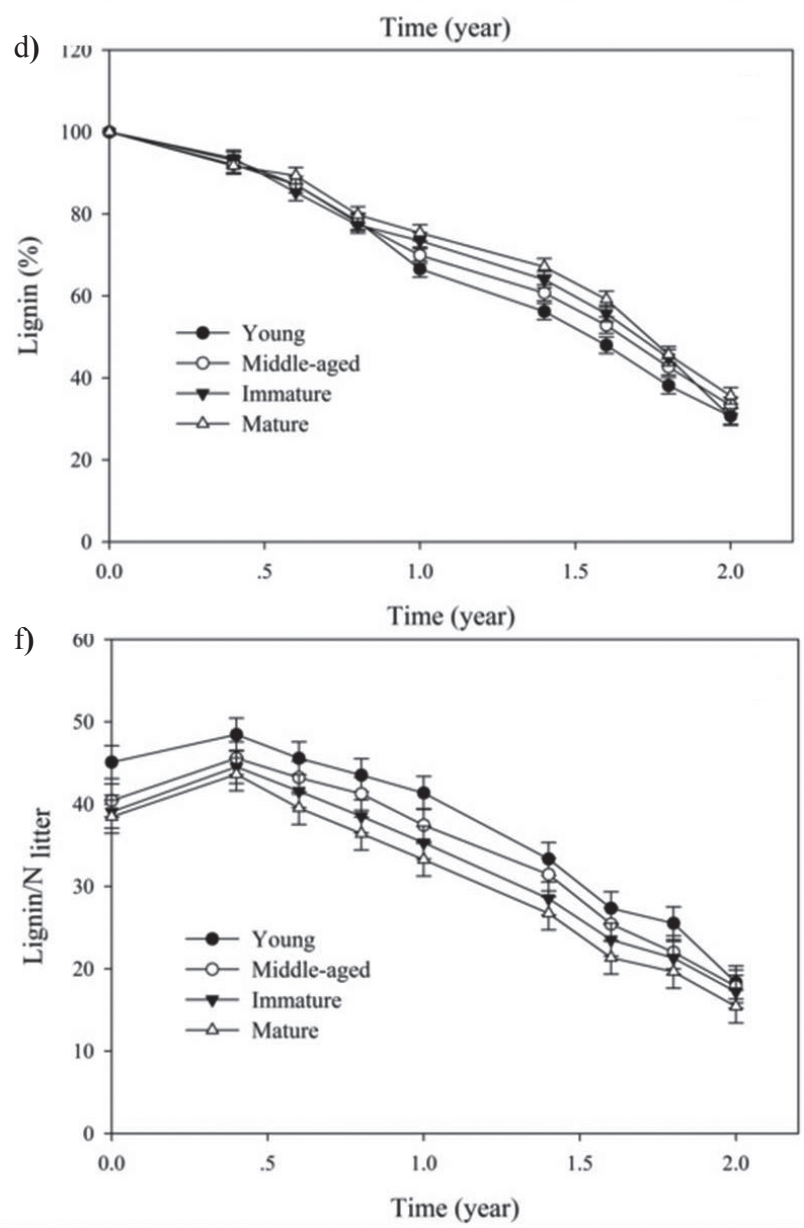

Fig. 2. Temporal changes in litter mass remaining, $\mathrm{C}$ retention, $\mathrm{N}$ retention, lignin retention, $\mathrm{C} / \mathrm{N}_{\text {litter }}$ ratio, and lignin $/ \mathrm{N}_{\text {litter }}$ ratio during litter decomposition across stand age classes in Pinus tabuliformis Carr. Forests; vertical bars indicate standard errors of means $(n=3)$. 
in the mean monthly soil water content among the four forest stand-age classes during the two growing seasons $(p<0.05)$, especially between May and August.

\section{Temporal Patterns of Litter Decomposition and Changes in Litter Chemistry Across Forest Stand Age Classes}

After 360 days, the rate of decomposition of the four forest stand age classes decreased in the following order: mature $>$ immature $>$ middle-aged $>$ young $(p<0.05$, Table 3). Specifically, cumulative mass losses of litter in young, middle-aged, immature, and mature stands were $21.86 \%, 23.23 \%, 26.07 \%$, and $26.67 \%$, respectively (Fig. 2a). Litter $\mathrm{C}$ retention rapidly declined in the first year of development and then decreased at a relatively slower rate during the remaining period of study. Moreover, there was a significantly $(p<0.05)$ lower rate of decline in litter $\mathrm{C}$ retention in mature stands than in other forest stand age groups (Fig. 2b).

The change in litter $\mathrm{N}$ retention during decomposition initially (0-210 days) exhibited a slight increase in all age groups and decreased thereafter. At the end of the study, the $\mathrm{N}$ retention in immature and mature forest stands was significantly greater than that in young and middle-aged forests stands (Fig. 2c).

Contrary to the patterns of changes in litter $\mathrm{C}$ retention, the patterns of changes in litter lignin retention experienced a slight decline during the first growing season, followed by a relatively faster and linear decrease at approximately the same level at the end of the study (Fig. 2d).

The patterns of changes in $\mathrm{C} / \mathrm{N}_{\text {litter }}$ during decomposition varied among all forest stand age groups (Fig. 2e). Specifically, the values of litter $\mathrm{C} / \mathrm{N}$ experienced an initial phase with a great increase in middle-aged forest stands, as well as a slight increase in immature and mature forest stands in the first year of deployment, and then settled down to become stable approximately within the range of 25-35 at the end of the study.

Changes in litter lignin/ $\mathrm{N}$ during decomposition displayed an initial phase of rapid increase across the entire age sequence and then exhibited an almost linear decreasing function during the remaining period of study (Fig. 2f). Specifically, the order of litter lignin/N was always as follows: mature $<$ immature $<$ middle-aged $<$ young ( $p<0.05$, Fig. $2 \mathrm{f}$ ) throughout the study period.

\section{Temporal Patterns of Changes in Soil Microbial Biomass Carbon, Basal Respiration, and Microbial Metabolic Quotient Across Forest Stand Age Classes}

Fig. 3 shows the variation in soil microbial indicators across the chronosequence of the forests during two growing seasons. In particular, the microbial biomass carbon (MBC) across the chronosequence sharply increased with the duration of decomposition up to its peak in August and drastically decreased thereafter
(Fig. 3a). On the whole, MBC exhibited a steady increase from young to mature stands. However, there was no significant difference in $\mathrm{MBC}$ between the young and middle-aged forest stands sampled in May and October, as well as the MBC between the immature and mature forest stands sampled in July 2013. In 2014 there was

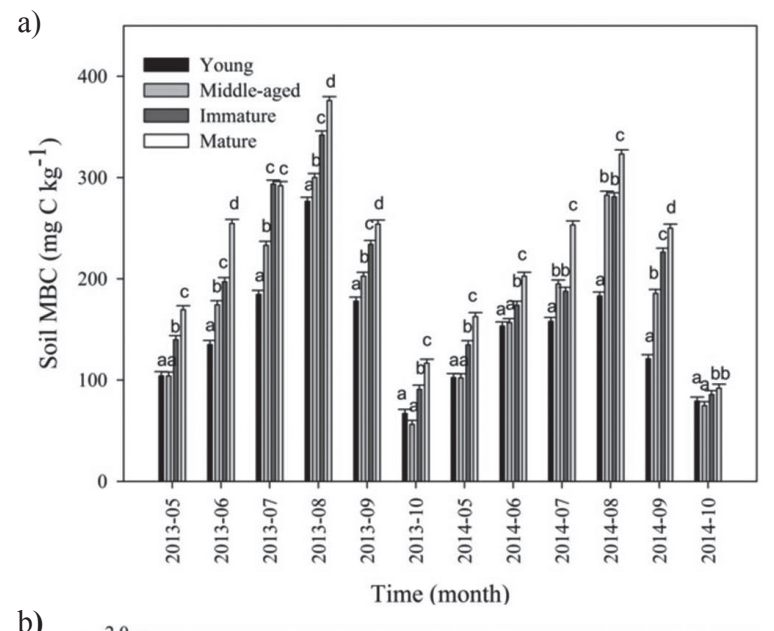

b)

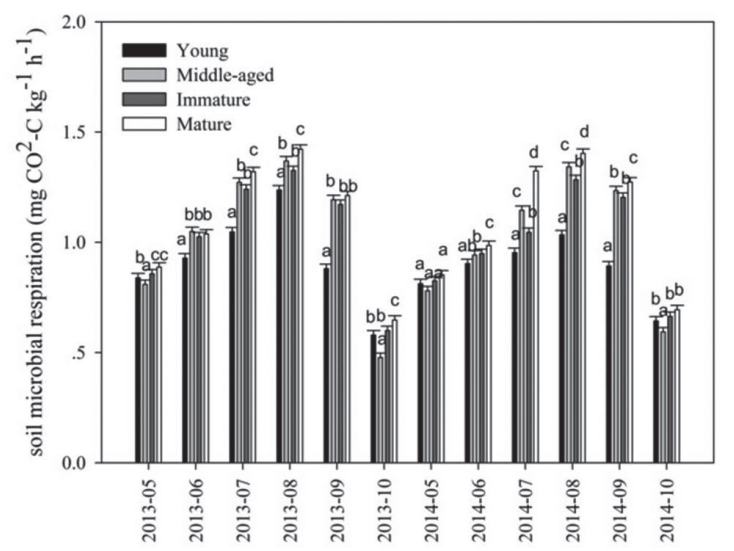

c)

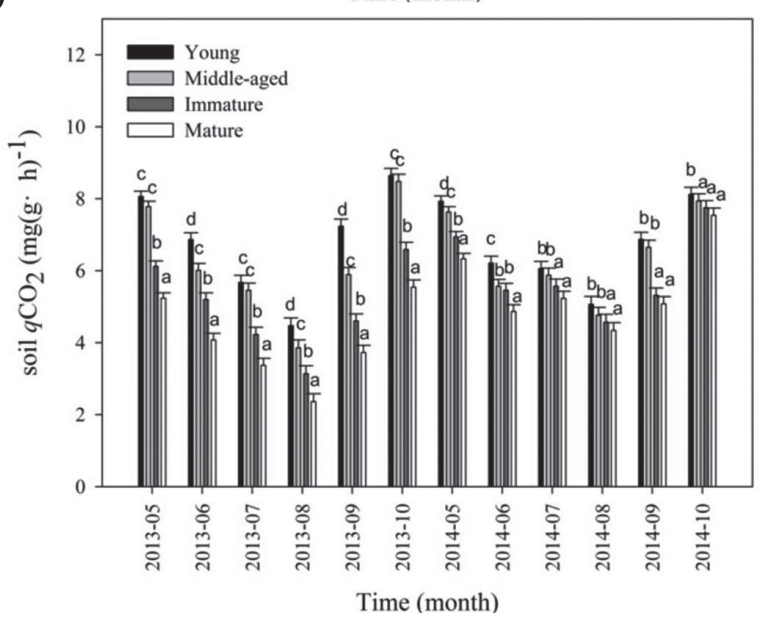

Fig. 3. Seasonal variation in soil microbial biomass carbon a), soil microbial respiration b), and soil microbial metabolic quotient c) of the four age classes in the Pinus tabuliformis Carr. forests during the growing season; different lowercase letters indicate a significant difference between age groups in the same depth at the same sampling time $(p<0.05)$; Error bars are SE of the mean $(n=3)$. 
Table 4. Shannon-Wiener index $(H)$, the richness of the DGGE bands $(S)$, and mass loss $(M)(\%)$ during the decomposition of Pinus tabuliformis Carr. natural secondary forests.

\begin{tabular}{|c|c|c|c|c|c|}
\hline \multirow{2}{*}{$\begin{array}{l}\text { Forest stand } \\
\text { age classes }\end{array}$} & & \multicolumn{4}{|c|}{ Sampling time(day) } \\
\hline & & 180 & 240 & 300 & 360 \\
\hline \multirow{3}{*}{ Young } & $H$ & 2.7 & 3.1 & 3.5 & 3.1 \\
\hline & $\mathrm{S}$ & 17 & 25 & 28 & 25 \\
\hline & $M$ & 11.6 & 17.9 & 21.8 & 29.5 \\
\hline \multirow{3}{*}{ Middle-aged } & $H$ & 2.8 & 3.2 & 3.7 & 2.9 \\
\hline & $S$ & 19 & 28 & 29 & 21 \\
\hline & $M$ & 12.2 & 18.7 & 23.3 & 27.9 \\
\hline \multirow{3}{*}{ Immature } & $H$ & 2.9 & 3.1 & 3.9 & 3.3 \\
\hline & $S$ & 22 & 27 & 31 & 26 \\
\hline & $M$ & 13.2 & 19.6 & 26.1 & 31.5 \\
\hline \multirow{3}{*}{ Mature } & $H$ & 3.8 & 3.9 & 4.1 & 3.3 \\
\hline & $S$ & 29 & 30 & 32 & 28 \\
\hline & $M$ & 13.9 & 21.2 & 26.7 & 36.8 \\
\hline
\end{tabular}

no significant difference in MBC between the young and middle-aged forest stands sampled in May, June, and October, as well as the MBC between the middle-aged and immature forest stands sampled in July, August, and October.

Similar to the trend of MBC, the soil basal respiration across the chronosequence steadily increased from May to August and then drastically decreased thereafter, with the minimum values in October. Moreover, soil basal respiration across all four age classes decreased in the following order: mature $>$ middle-aged $>$ immature $>$ young during the two growing seasons (Fig. 3b). However, there was no significant difference in soil basal respiration among the chronosequence stands in May and October over the two growing seasons.

However, the metabolic quotient $\left(q \mathrm{CO}_{2}\right)$ pattern exhibited the opposite trend toward the soil MBC and basal respiration, which prominently decreased in the first four months, with the minimum values in August, but drastically increased in the latter two months of the experiment (Fig. 3c). Moreover, the $q \mathrm{CO}_{2}$ significantly decreased as the stand age increased during the first growing season.

\section{Temporal Patterns of Soil Diversity of Fungal Assemblages Across Forest Stand Age Classes}

Fingerprinting analysis of the fungal assemblages based on the PCR-DGGE technique indicated significant differences between the numbers of DGGE bands across forest stand age classes during decomposition (Table 4). The initial numbers of DGGE bands were low and increased to reach the maximum values at day 300 , after which they decreased dramatically on day 360 (Table 4). In addition, the numbers of DGGE bands increased from young to mature stands along the chronosequence. In addition, the diversity reflected by the Shannon-Wiener indices exhibited similar patterns to the variations in the DGGE bands.

\section{Biotic and Abiotic Factor Controls on Litter Decomposition}

The best-fit path model identified Lignin/ $\mathrm{N}, \mathrm{qCO}_{2}$, $\mathrm{SFD}$, and SMC as the most prominent factors controlling the rate of litter decomposition (Fig. 4). During the two growing seasons, the path analysis identified the litter lignin/ $\mathrm{N}$ ratio, soil microbial metabolic quotient $\left(q \mathrm{CO}_{2}\right)$,

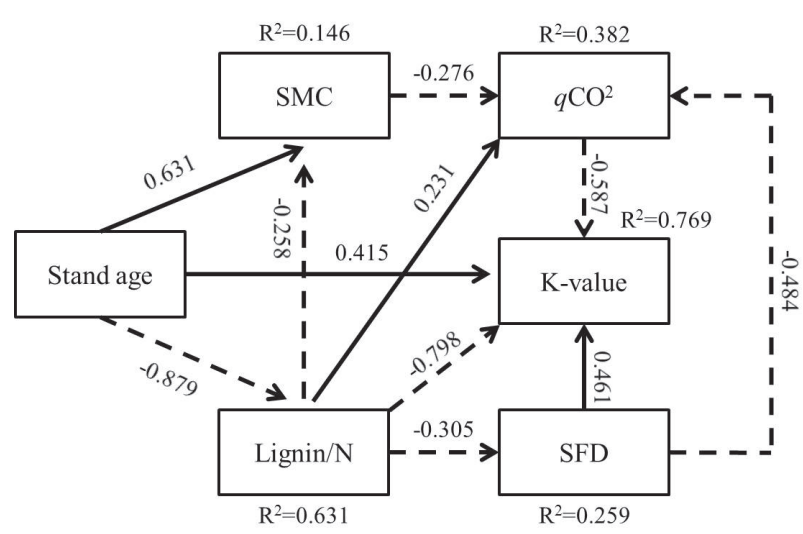

Fig. 4. Path model illustrates direct and indirect effects of abiotic and biotic factors on litter decomposition; values on arrows are standardized direct path coefficient, solid arrow lines represent positive effects, and dash arrow lines indicate negative effects; $R^{2}$ value represents the proportion of total variance explained for the specific dependent variable. 
soil diversity of fungal assemblages (SFD), and soil water content (SWC) as dominant controlling factors in needle litter decomposition, collectively explaining $76.9 \%$ of the total variation in mass loss across the entire age sequence. Specifically, the model explained more than $60 \%$ of the variance in $\mathrm{k}$ and Lignin/ $\mathrm{N}$ and $38.2 \%, 25.9 \%$ and $14.6 \%$ of the variance in $q \mathrm{CO}_{2}, \mathrm{SFD}$, and $\mathrm{SMC}$, respectively. Among the four explanatory variables, Lignin/ $\mathrm{N}$ and $q \mathrm{CO}_{2}$ had the greatest negative effect on the $\mathrm{k}$ value, followed by positive effects of SFD. In addition, Lignin/ $\mathrm{N}$ also had strong negative effects on SMC and SFD. Apart from the strong negative effect of Lignin/N, SFD was also strongly and positively affected by $q \mathrm{CO}_{2}$.

\section{Discussion}

In this study, we found significant differences in decomposition rates among needle litter across a chronosequence of Chinese pine forests in northern China. Biotic and abiotic factors greatly contributed to the variations in litter decomposition.

Initial litter qualities such as $\mathrm{N}, \mathrm{C} / \mathrm{N}$, and lignin concentrations were the best direct predictors of needle litter decomposition in various ecosystems [37-39]. Specifically, litter from older forests contained relatively higher levels of $\mathrm{N}$ concentration and lower $\mathrm{C} / \mathrm{N}$ and lignin/ $\mathrm{N}$ ratios than litter from younger forests [40]. Moreover, Jacob found that the rate of litter decomposition was positively associated with initial $\mathrm{N}$ concentrations but negatively associated with lignin/ $\mathrm{N}$ and $\mathrm{C} / \mathrm{N}$ ratios [41]. Therefore, the litter decomposition rates exhibited an increasing trend with increasing stand age. A possible explanation for the observed difference in decomposition rates across the age sequence could be the nutrients obtained from plant roots and leaf photosynthesis [8, 42]. Zhao et al. found that with the increase in the forest stand age, the number and size of Pinus tabuliformis Carr. roots gradually increased, and the biodiversity of shrub and herb undergrowth became more abundant, which could absorb huge amounts of nutrients from the soil for leaf litter growth [43]. In turn, more litter fall and decomposition accumulated more organic matter in soils [44]. Therefore, such a positive cycle accelerated the accumulation of nutrients in leaf litter with the increase in the forest stand age. Leaf litter in mature stands had the highest quality and decreased with decreasing forest stand age, which facilitated the abundance of microflora and microbial activities to efficiently decompose litter [36, 45-46].

Our path analysis identified a direct and significant $(P<0.05)$ control of soil $q \mathrm{CO}_{2}$ and SFD on litter decomposition. Specifically, the microbial metabolic quotient $\left(q \mathrm{CO}_{2}\right)$ is a sensitive index that reflects the influence of environmental factors on the microbial carbon pool, combining microbial activity with microbial biomass carbon and microbial respiration to indirectly evaluate microbial activities associated with litter decomposition [47-50]. In addition, Liu et al. found that the lower the $q \mathrm{CO}_{2}$ value, the smaller the amount of carbon consumed by microbial respiration, while the proportion of carbon used by the construction of microbial cells relatively increased, which controlled the composition and diversity of microbial communities [48, 51-52]. In this study, the indices of soil biological activities increased with increasing stand age, and this was attributed to the following reasons. First, soil biological activities were regulated by leaf litter quality due to the differences in initial nutrient concentrations and rates of decomposition [53-54]. With the forest growth, litter would have more organic $\mathrm{C}$, total $\mathrm{N}$, and any other nutrients, which may contribute to the increase of abundance and activity of decomposers $[52,55-56]$. Second, this could be because the older stand developed long enough to accumulate higher contents of nutrient resources and create more favourable habitat heterogeneity [12]. However, most of all, soil microbes act as the only vital organism playing important roles in biogeochemical cycles, energy transfer, and soil formation [57]. In turn, soil quality would influence the quantity and composition of the decomposer community. Thus, older forest stands have more microbial numbers and more microbial activity to efficiently decompose litter [58]. Third, with the increasing stand age, the canopy density of the forest stand could decrease due to the self-thinning rule, which greatly improved the temperature, moisture content in soil, and light intensity in the forest, making it more suitable for microbial growth and reproduction [59].

All of the soil biological activities exhibited significant temporal variation (Fig. 3). The results suggested that higher temperature accelerated microbial growth and activities to fix more carbon, intensifying microbial respiration [60]. Additionally, precipitation during the rainy season could accelerate the leaching of water-soluble substances from litter to soil, which provides nutrients available for microbial growth. These, in turn, might have had positive effects on soil biological activities [61]. Therefore, the temporal patterns of soil biological activities reflected the availability and rate of utilization of nutrient resources, as well as good adaptation to favourable environmental conditions [62].

Our findings suggest that forest stand age plays a primary role in controlling litter decomposition by determining the leaf litter quality, with soil biotic and abiotic conditions being secondary factors contributing to the variations in leaf litter decomposition across a chronosequence of Chinese pine forests. In addition, forest stand age could improve soil fertility through the input of nutrient elements, which indirectly control litter decomposition through soil microbial community diversity and microbial activity. Therefore, understanding the dominant factors driving litter decomposition is critically important for exploring nutrient cycling and sustaining the site productivity of forest ecosystems. 


\section{Conclusions}

Forest stand age was confirmed to be a crucial driver of intraspecific variation in litter quality. In addition, decomposition rates and all soil biological parameters increased with increasing stand age, and the soil ecosystem tended to be stable. Our findings indicated that forest stand age had a great influence on needle litter decomposition by determining the litter quality, with soil microbial activity and local environmental factors being secondary drivers in needle litter decomposition across a chronosequence of Chinese pine forests. Therefore, consideration of forest stand age is critically important in assessing the needle litter decomposition of temperate Chinese pine forest ecosystems.

\section{Acknowledgements}

This project was supported by CFERN\&GENE (forest ecological service function distributed localization observation and model simulation) award funds and the National Forestry Public Welfare Professional Scientific Research Project (No. 201204101). The authors thank all those who provided helpful suggestions and critical comments on this manuscript and anonymous reviewers. We gratefully acknowledge the support of Weimin $\mathrm{Hu}$ and Shuwen Han from the Pingquan Forestry Bureau and Liao River Source Forest Ecological Research Station for their support in fieldwork.

\section{Conflict of Interest}

The authors declare no conflict of interest.

\section{References}

1. MOORE J.C., BERLOW E.L., COLEMAN D.C., DE RUITER P.C., DONG Q., HASTINGS A., JOHNSON N.C., MCCANN K.S., MELVILLE K., MORIN P.J., NADELHOFFER K., ROSEMOND A.D., POST D.M., SABO J.L., SCOW K.M., VANNI M.J., WALL D.H., Detritus, trophic dynamics and biodiversity. Ecol. Lett., 7, 584, 2004.

2. HOORENS B., DAVID C., RIEN A., Neighbour identity hardly affects litter-mixture effects on decomposition rates of New Zealand forest species. Oecologia, 162, 479, 2010.

3. BERG B., DAVEY M., DE MARO A., EMMETT B., FAITURI M., SASWAT S., JOHANSSON M.B., LIU C., MCCLAUGHERTY C., NORELL L., RUTIGLIANO F., VESTERDAL L., DE VIRZO S.A. Factors influencing limit values for pine needle litter decomposition: a synthesis for boreal and temperate pine forest systems. Biogeochemistry, 100, 57, 2010.

4. APONTE C., GARCIA L.V., MARANON T., Tree Species Effect on Litter Decomposition and Nutrient Release in Mediterranean Oak Forests Changes Over Time. Ecosystems, 15, 1204, 2012.

5. CHENG F., PENG X.B., ZHAO P., YUAN J., ZHONG C., CHENG Y.L., CUI C., ZHANG S.X., Soil Microbial
Biomass, Basal Respiration and Enzyme Activity of Main Forest Types in the Qinling Mountains. PLoS ONE, 8, e67353, 2013.

6. ALBERT C.H., DE BELLO F., BOULANGEAT I., PELLET G., LAVOREL S., THUILLER W., On the importance of intraspecific variability for the quantification of functional diversity. Oikos, 121, 116, 2012.

7. HATTENSCHWILER S., JORGENSEN H.B., Carbon quality rather than stoichiometry controls litter decomposition in a tropical rain forest. J. Ecol., 98, 754, 2010.

8. TRAP J., HATTENSCHWILER S., GATTIN I., AUBERT M., Forest stand ageing: An unexpected driver of beech leaf litter quality variability in European forests with strong consequences on soil processes. Forest Ecology and Management, 302, 338, 2013.

9. MATTHIEU C., ANDREI S.Z., ERNST G., VOLKMAR W., How do soil fauna and soil microbiota respond to beech forest growth? Current Zoology, 55, 272, 2009.

10. TRAP J., LAVAL K., AKPAK-VINCESLAS M., GANGNEUX C., DECAENS T., AUBERT M., Humus macro-morphology and soil microbial community changes along a 130-yr-old Fagus sylvatica chronosequence. Soil Biology and Biochemistry, 43, 1553, 2011.

11. MERILA P., MALMIVAARA-LAMASA M., SPETZ P., STARK S., VIERIKKO K., DEROME J., FRITZE H., Soil organic matter quality as a link between microbial community structure and vegetation composition along a successional gradient in a boreal forest. Appl. Soil Ecol., 46, 259, 2010.

12. JANUSAUSKAITE D., BALIUCKAS V., ZENONAS D., Needle Litter Decomposition of Native Pinus sylvestris L. and Alien Pinus mugo at Different Ages Affecting Enzyme Activities and Soil Properties on Dune Sands. BALTIC FORESTRY, 19, 50, 2013.

13. MUKHOPADHYAY S., JOY V.C., Influence of leaf litter types on microbial functions and nutrient status of soil: Ecological suitability of forest trees for afforestation in tropical laterite wastelands. Soil Biology \& Biochemistry 42, 2306, 2010.

14. XIAO W.F., GE X.G., ZENG L.X., HUANG Z.L., LEI J.P., ZHOU B.Z., LI M.H., Rates of Litter Decomposition and Soil Respiration in Relation to Soil Temperature and Water in Different-Aged Pinus massoniana Forests in the Three Gorges Reservoir Area, China. PLoS ONE, 9, e101890, 2014.

15. BERBECO M.R., MELILLO J.M., ORIANS C.M., Soil warming accelerates decomposition of fine woody debris. Plant and soil, 344, 1000, 2012.

16. FIERE N., CRAINE J.M., MCLAUCHLAN K., SCHIML J.P., Litter quality and the temperature sensitivity of decomposition. Ecology, 86, 320, 2005.

17. CORTEZ J., Field decomposition of leaf litters: relationship between decomposition rates and soil moisture, soil temperature and earthworm activity. Soil Biology and Biochemistry, 30, 783, 1998.

18. WANG C.Y., HAN G.M., JIA Y., FENG X.G., TIAN X.J., Insight into the temperature sensitivity of forest litter decomposition and soil enzymes in subtropical forest in China. Journal of Plant Ecology, 5, 279, 2012.

19. FAO, ISRIC, ISSS World Reference Base for Soil Resources. Report No. 103. World Soil Resources Reports, Rome. 2006.

20. Forestry Standards "Observation Methodology for Longterm Forest Ecosystem Research" of People's Republic of China (LY/T 1952-2011), FERN: Beijing, China, 2011. 
21. NELSON D., SOMMERS L., Total carbon, organic carbon, and organic matter. In: SPARKS D.L., PAGE A.L., HELMKE P.A., LOEPPERT R.H., SOLTANPOUR M.A., TABATABAI M.A., JOHNSTON C.T., SUMNER M.E., Methods of soil analysis. Part 3, Chemical methods. Soil Science Society of America, American Society of Agronomy, Madison, 961, 1996.

22. KEENEY D.R., NELSON D.W., Nitrogen-inorganic forms. In Methods in soil analysis. Part 2. Chemical and microbiological properties. Edited by A.L. Page and R.H. Miller. American Society of Agronomy, Madison, Wis. 643, 1982.

23. ROWLAND A.P., ROBERTS J.D., Lignin and cellulose fractionation in decomposition studies using acid-detergent fiber methods. Commun Soil Sci Plan, 25, 269, 1994.

24. GELSOMINO A., AZZELLINO A., Multivariate analysis of soils: microbial biomass, metabolic activity, and bacterial community structure and their relationships with soil depth and type. Journal of Plant Nutrition and Soil Science, 174, 381, 2011.

25. WARDLE D.A., Comparative assessment of factors which influence microbial biomass carbon and nitrogen levels in soil. Biol. Rev. Camb. Philos. Soc., 67, 321, 1992.

26. VANCE E.D., BROOKES P.C., JENKINSON D.S., An extraction method for measuring soil microbial biomass $\mathrm{C}$. Soil Biology and Biochemistry, 19, 703, 1987.

27. MAITY S.K., JOY V.C., Effect of polyphenols in leaf litter on energy content and respiration of soil arthropod species. International Journal of Ecology and Environmental Sciences, 27, 45, 2001.

28. ANDERSON J.P.E., DOMSCH K.H., The metabolic quotient for $\mathrm{CO}_{2}\left(\mathrm{qCO}_{2}\right)$ as a specific activity parameter to assess the effects of environmental conditions, such as $\mathrm{pH}$, on the microbial biomass of forest soils. Soil Biol. Biochem., 25, 393, 1993.

29. GAO J., KANG F.F., LI T.Y., SONG X.S., ZHAO W.H., YU X.W., HAN H.R., Assessing the Effect of Leaf Litter Diversity on the Decomposition and Associated Diversity of Fungal Assemblages. Forests, 6, 2371, 2015.

30. OLSON J.S., Energy storage and balance of producers and decomposers in ecological systems. Ecology, 44, 322, 1963.

31. BARLOCHER F., Leaf mass loss estimated by litter bag technique. In: Graca MAS, Barlocher F, Gessner MO (eds) Methods to study litter decomposition - a practical guide. Springer, Dordrecht, 37, 2007.

32. BELL T., AGER D., SONG J.I., NEWMAN J.A., THOMPSON I.P., LILLEY A.K., VAN DER GAST C.J., Larger islands house more bacterial taxa. Science, 308, 1884, 2005.

33. RECHE I., PULIDO-VILLENA E., MORALESBAQUERO R., CASAMAYOR E.O., Does ecosystem size determine aquatic bacterial richness? Ecology, 86, $1715,2005$.

34. TREVORS J.T., KEVAN P.G., TAM L., Microbial diversity across a Canadian sub-Arctic, isostatically rebounding, soil transect. Polar Sci., 4, 81, 2010.

35. GRACE J.B., MICHAEL A.T., SMITH M.D. Does species diversity limit productivity in natural grassland communities? Ecol. Lett., 10, 680, 2007.

36. WANG J., YOU Y.M., TANG Z.X., LIU S.R., SUN O.J.X., Variations in leaf litter decomposition across contrasting forest stands and controlling factors at local scale. Journal of Plant Ecology, 8, 261, 2014.
37. WU D.D., LI T.T., WAN S.Q., Time and litter species composition affect litter-mixing effects on decomposition rates. Plant Soil, 371, 355, 2013.

38. TALBOT J.M., YELLE D.J., NOWICK J., TRESEDER K.K., Litter decay rates are determined by lignin chemistry. Biogeochemistry, 108, 279, 2012

39. PRESCOTT C.E., Litter decomposition: what controls it and how can we alter it to sequester more carbon in forest soils? Biogeochemistry, 101, 133, 2010.

40. RYAN M.G., BINKLEY D., FOWNES J.H., Age-related decline in forest productivity: Pattern and process. In: Advances in Ecological Research, Academic Press Ltd., London, 27, 213, 1997.

41. JACOB M., VIEDENZ K., POLLE A., Leaf litter decomposition in temperate deciduous forest stands with a decreasing fraction of beech (Fagus sylvatica). Oecologia, 164, 1083, 2010.

42. BRAIS S., CAMIRE C., BERGERON Y.P.D., Changes in nutrient availability and forest floor characteristics in relation to stand age and forest composition in the southern part of the boreal forest of northwestern Quebec. Forest Ecology and Management, 76, 181, 1995.

43. ZHAO J.L., KANG F.F., WANG L.X., YU X.W., ZHAO W.H., SONG X.S., ZHANG Y.L., CHEN F., SUN Y., HE T.F., HAN H.R., Patterns of Biomass and Carbon Distribution across a Chronosequence of Chinese Pine (Pinus tabulaeformis) Forests. PLoS ONE, 9, e94966, 2014.

44. CHENG X.Q., HAN H.R., KANG F.F., SONG Y.L., LIU $\mathrm{K}$., Variation in biomass and carbon storage by stand age in pine (Pinus tabulaeformis) planted ecosystem in Mt. Taiyue, Shanxi, China. Journal of Plant Interactions, 9, 521, 2014.

45. VIVANCO L., AUSTIN A.T., Nitrogen addition stimulates forest litter decomposition and disrupts species interactions in Patagonia, Argentina. Glob Change Biol., 17, 1963, 2011.

46. LIU P., HUANG J., SUN O.J., HAN X., Litter decomposition and nutrient release as affected by soil nitrogen availability and litter quality in a semiarid grassland ecosystem. Oecologia, 162, 771, 2010.

47. ANANYEUA N.D., SUSYAN E.A., CHERNOVA O.V., WIRTH S., Microbial respiration activities of soil from different climatic regions of European Russia. European Journal of Soil Biology, 44, 147, 2008.

48. LIU J., XIA H.J., WANG J.Z., ZHANG W.L. Bioactive characteristics of soil microorganisms in different-aged orange (citrus reticulate) plantations. Agricultural Science \& Technology, 13, 1277, 2012.

49. VIVANCO L., AUSTIN A.T., Tree species identity alters forest litter decomposition through long-term plant and soil interactions in Patagonia, Argentina. J Ecol., 96, $727,2008$.

50. BOLAT I., The effect of thinning on microbial biomass $\mathrm{C}, \mathrm{N}$ and basal respiration in black pine forest soils in Mudurnu, Turkey. Eur J Forest Res., 133, 131, 2014.

51. BORKEN W., MUHS A., BEESE F., Application of compost in spruce forests: effects on soil respiration, basal respiration and microbial biomass. Forest Ecology and Management, 159, 49, 2002.

52. YOU Y., WANG J., HUANG X., TANG Z., LIU S., SUN O.J., Relating microbial community structure to functioning in forest soil organic carbon transformation and turnover. Ecol Evol., 4, 633, 2014.

53. GAMA-RODRIGUES E.F., BARROS N.F., GAMARODRIGUES A.C., SANTOS G.A., Carbon, nitrogen and activity of microbial biomass in soil under eucalypt plantations. Rev. Bras. Cienc. Solo., 29, 893, 2005. 
54. ROUIFED S., HANDA I.T., DAVID J.F., HATTENSCHWILER S., The importance of biotic factors in predicting global change effects on decomposition of temperate forest leaf litter. Oecologia, 163, 247, 2010.

55. BALDOCK J.A., Composition and cycling of organic carbon in soil. In: Marschner, P., Rengel, Z. (Eds.), Nutrient Cycling in Terrestrial Ecosystems, Part-1. Soil Biology, 10, $1,2007$.

56. CONN C., DIGHTON J., Litter quality influences on decomposition, ectomycorrhizal community structure and mycorrhizal root surface acid phosphatase activity. Soil Biol. Biochem., 32, 489, 2000.

57. DIAZ-RAVINA M., ACEA M.J., CARBALlAS T., Microbial biomass and its contribution to nutrient concentrations in forest soils. Soil Biol. Biochem., 25, 25, 1993.

58. HOPKINS D.W., BADALUCCO L.C., ENGLISH S.M., MELI J., CHUDEK A., IOPPOLO A., Plant litter decomposition and microbial characteristics in volcanic soils (Mt Etna. Sicily) at different stages of development. Biology and Fertility of Soils, 43, 461, 2007.
59. BRANDSTATTER C., KATHARINA K., WANEK W., SOPHIE Z.B., A closeup study of early beech litter decomposition: potential drivers and microbial interactions on a changing substrate. Plant Soil, 371, 139, 2013.

60. PASCOAL C., CASSIO F., Contribution of fungi and bacteria to leaf litter decomposition in a polluted river. Applied and Environmental Microbiology, 70, 5266, 2004.

61. BALDRIAN P., SNAJDR J., MERHAUTOV V., DOBIASOVA P., CAJTHAML T., VALASKOVA V., Responses of the extracellular enzyme activities in hardwood forest to soil temperature and seasonality and the potential effects of climate change. Soil Biology \& Biochemistry, 56, 60, 2013.

62. KOTROCZO Z., VERES Z., FEKETE I., KRAKOMPERGER Z., TORTH J.A., LAJTHA K., TOTHMERESZ B., Soil enzyme activity in response to long-term organic matter manipulation. Soil Biology \& Biochemistry, 70, 237, 2014. 